\title{
Application Design of Web-based Computer Laboratory Inventory and Maintenance System at SMK Bhakti Anindya
}

\section{Rancangan Aplikasi Perawatan dan Inventaris Laboratorium Komputer Berbasis Web pada SMK Bhakti Anindya}

\author{
Reza Syafrizal $^{*}$, Sarmuni ${ }^{1}$, Rizki Aibar $^{2}$
}

\begin{abstract}
This paper describes a problem in computer laboratory maintenance and inventory. Inventory of goods in Every company or institution always has a connection with the data management process of goods / equipment owned by the company. In addition to inventory, maintenance is also very necessary in order to keep company assets under control, safe, and always maintained. For this reason, an Inventory Information System is needed as well as a maintenance system in managing the data. The results of this design are focused on managing information about the management of goods and several aspects regarding the maintenance of goods, especially in the computer laboratory of SMK Bhakti Anindya. With the implementation of the maintenance information system and laboratory inventory at Bhakti Anindya Vocational School, data management and equipment maintenance will be better..
\end{abstract}

Keywords

Information Systems, Maintenance and Inventory Lab, Computer Laboratory

\begin{abstract}
Abstrak
Tulisan ini menjelaskan mengenai sebuah permasalahan dalam perawatan dan inventaris laboratorium komputer. Inventarisasi barang dalam Setiap perusahaan atau sebuah lembaga selalu memiliki keterkaitan dengan proses pengelolaan data barang / peralatan yang di miliki oleh perusahaan tersebut. Disamping inventarisasi, hal perawatan juga sangat diperlukan demi menjaga agar aset perusahaan terkontrol, aman, dan selalu terawat. Untuk itulah di butuhkan suatu Sistem Informasi Inventaris sekaligus sistem perawatannya dalam mengelola data tersebut. Hasil dari rancang bangun ini dititik beratkan pada pengelolaan informasi tentang pengelolaan barang dan beberapa aspek mengenai perawatan barang terutama pada bagian laboratorium komputer SMK Bhakti Anindya. Dengan diimplementasikannya sistem informasi Perawatan dan inventaris laboratorium di SMK Bhakti Anindya, pengelolaan data barang dan perawatan alat akan lebih baik.
\end{abstract}

\section{Kata Kunci}

Sistem Informasi, Perawatan dan Inventaris Lab, Laboratorium Komputer.

${ }^{1}$ UIN Sultan Maulana Hasanuddin Banten

Jalan Jend. Sudirman No. 30, Kota Serang

2 SMK Bhakti Anindya

Jalan KS Tubun No. 11, Pasar Baru, Kota Tangerang

*reza.syafrizal@uinbanten.ac.id

Submitted : August 26, 2021. Accepted : September 21, 2021. Published : September 22, 2021. 


\section{PENDAHULUAN}

Perkembangan teknologi informasi saat ini sudah sedemikian maju, siapapun yang mengikuti perkembangan dalam dunia informasi akan merasa bahwa perkembangan ini terlalu cepat untuk disesuaikan dengan pertumbuhan organisasi atau suatu instansi. Searah dengan perkembangan teknologi sistem informasi, banyak hal yang membuat kemudahan dalam mengerjakan suatu pekerjaan.

Pada organisasi di bidang pendidikan tidak akan lepas dari kegiatan pengolahan data, baik secara manual ataupun dengan cara elektronik. Pengolahan data, bukan sekedar kegiatan tulis menulis, menyimpan berkas. Pengolahan data merupakan suatu hal rutinitas organisasi sehingga perlu dibudayakan dengan baik dan benar supaya menghasilkan suatu informasi yang akurat. Pendidikan memegang peranan yang sangat penting dalam meningkatkan kecerdasan bangsa dan merupakan faktor kunci dalam perkembangan pembangunan bangsa di segala bidang sesuai dengan perkembangan ilmu pengetahuan dan teknologi yang semakin pesat dewasa ini.

Pada laboratorium SMK Bhakti Anindya saat ini sudah banyak alat-alat praktikum yang dapat digunakan, baik siswa maupun guru. Perawatan dan pengelolaan data untuk saat ini masih menggunakan sistem manual, bahkan masih berbasis kertas dalam bentuk catatan dalam perawatan dan inventarisir peralatan yang ada. Selain itu, ada juga menggunakan komputer sebagai pencatatan administrasi maupun manajemen, namun masih sebatas untuk mengetik data inventaris dan belum menggunakan program khusus untuk membuat laporan yang berhubungan dengan pengolahan data maupun inventaris, bahkan masih menggunakan lisan dalam laporannya, sehingga mengakibatkan sering terjadi kesalahpahaman dan juga sering terjadi keterlambatan dalam inventarisasi, maka diperlukan sebuah sistem aplikasi dengan menggunakan program khusus untuk mengolah data yang meliputi data inventaris alat dan bahan, serta pengelolaan data untuk laporan kegiatan dan perawatan laboratorium.

Dengan adanya sistem baru akan membantu staff laboran SMK Bhakti Anindya dalam pengelolaan data perawatan dan inventaris dapat terarah serta lebih efektif dan efisien dalam memonitoring kondisi laboratorium, mendapatkan informasi yang didapat dengan baik dan akan membantu kepala sekolah dalam menerima laporan data inventaris serta dapat menyajikan informasi yang cepat dan akurat kepada pengguna lainnya.

\section{Sistem}

Sistem didefinisikan sebagai sekumpulan komponen yang terdiri dari sub-sistem fisik dan non-fisik/logika yang saling berhubungan satu sama lainnya dan bekerja sama untuk mencapai suatu tujuan [1].

\section{Sistem Informasi Laboratorium}

Gabungan kedua kata tersebut, sistem informasi dapat didefinisikan sebagai kumpulan elemen yang saling berhubungan satu sama lain yang membentuk satu kesatuan yang berfungsi untuk mengintegrasikan data, memproses dan menyimpan serta mendistribusikan informasi [2]. Laboratorium adalah tempat yang digunakan kegiatan percobaan atau penyelidikan dalam bidang ilmu tertentu seperti fisika, kimia, biologi dan sebagainya [3].

\section{Konsep Dasar Maintenance (Perawatan )}

Perawatan (maintenance) ialah suatu kegiatan yang dilakukan secara sengaja (sadar) terhadap suatu fasilitas dengan menganut suatu sistematika tertentu untuk mencapai hasil telah ditetapkan [4]. Dalam pengembangan penelitian ini beberapa acuan peneliti sebelumnya juga penulis gunakan terutama pengembangan aplikasi-aplikasi yang digunakan di kampus [5][6]. 


\section{METODE PENELITIAN}

Metode yang digunakan dalam penulisan ini adalah pendekatan metode waterfall yang digambarkan dengan diagram pada gambar 1.

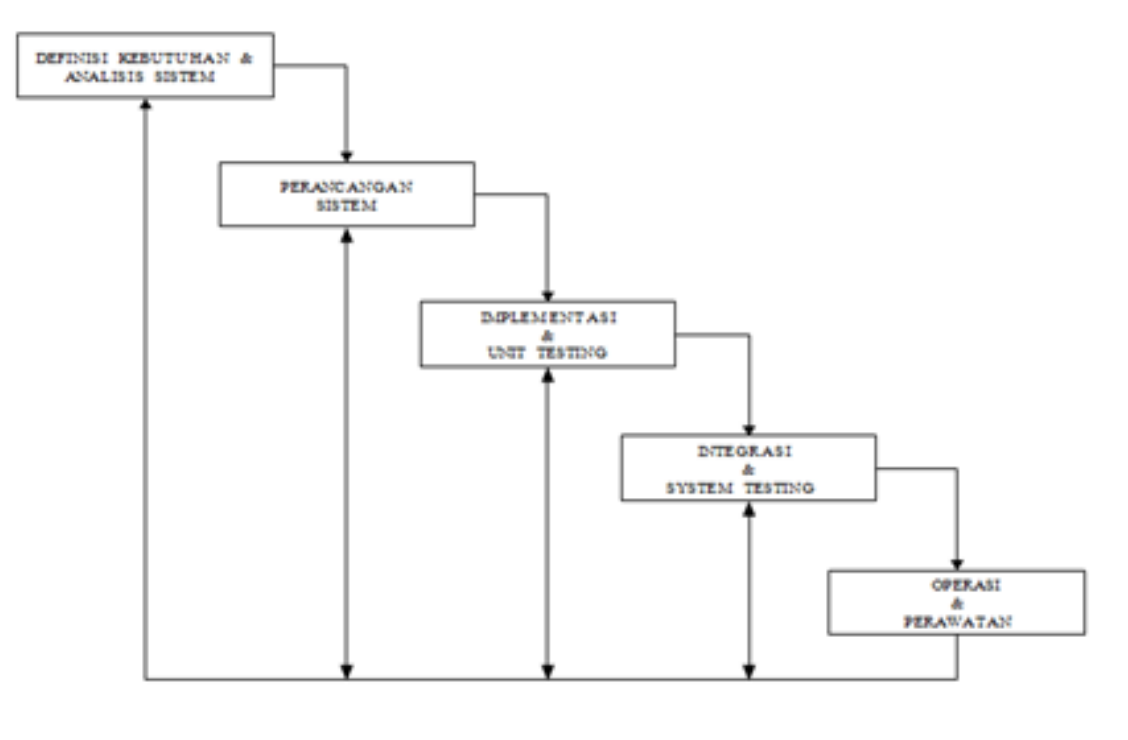

Gambar 1. Ilustrasi model waterfall

\section{Definisi kebutuhan dan analisis sistem}

Tahap ini digunakan untuk menjelaskan kelemahan sistem yang lama, dan menganalisa kebutuhan-kebutuhan dalam sistem yang diusulkan.

\section{Perancangan sistem}

Pada tahap ini dibuat perancangan sistem sesuai dengan spesifikasi kebutuhan sistem yang telah diuraikan pada tahap sebelumnya. Langkah-langkah dalam tahap perancangan, meliputi: perancangan prosedural antara lain : perancangan sistem, struktur menu dan perancangan antarmuka

\section{Implementasi dan unit testing}

Merupakan tahapan dalam pembuatan perangkat lunak dan pengujian kesesuaiannya antara spesifikasi kebutuhan sistem, perancangan sistem dan perangkat lunak yang dibangun, sehingga dapat diketahui apakah sistem sudah memenuhi seluruh kebutuhan sistem atau belum.

\section{Integrasi dan system testing}

Pada tahap ini akan dilakukan proses pembentukan kesatuan sistem yang didalamnya terdiri dari pengintegrasian unit-unit, kemudian diuji kembali sebagai satu kesatuan sistem yang utuh.

\section{Operasi dan perawatan}

Tahap dimana sistem digunakan dan dilakukan upaya perbaikan, perubahan dan pengembangan sistem jika diperlukan.

\section{HASIL DAN PEMBAHASAN}

Setelah mengadakan penelitian dan analisa sistem yang berjalan, maka selanjutnya akan dibahas mengenai rancangan sistem usulan yang akan dibangun. Dimulai dari kelemahan sistem manual, melakukan perencanaan sistem dan melakukan pembuatan aplikasi. Dengan adanya sebuah sistem aplikasi, bisa menjadi solusi yang tepat dari permasalahan yang ada. 


\section{Use Case Diagram}

Use case diagram digunakan untuk menggambarkan urutan interaksi aktor pada sistem. Use case yang akan dirancang yaitu untuk aktor user sebagai laboran. Use case diagram user sebagai aktor pada sistem dapat diihat pada gambar 2 .

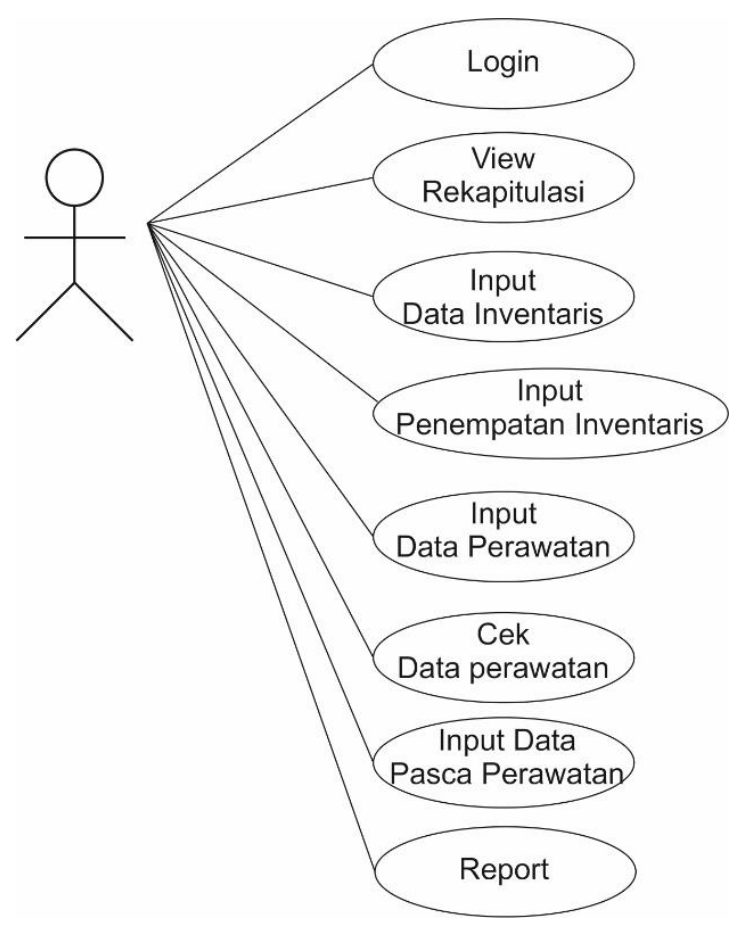

\section{Class Diagram}

Gambar 2. Use case dari actor user sebagai laboran

Class diagram memberikan gambaran- gambaran mengenai penjelasan class serta objek yang terhubung. Class diagram dapat dilihat pada gambar 3 .
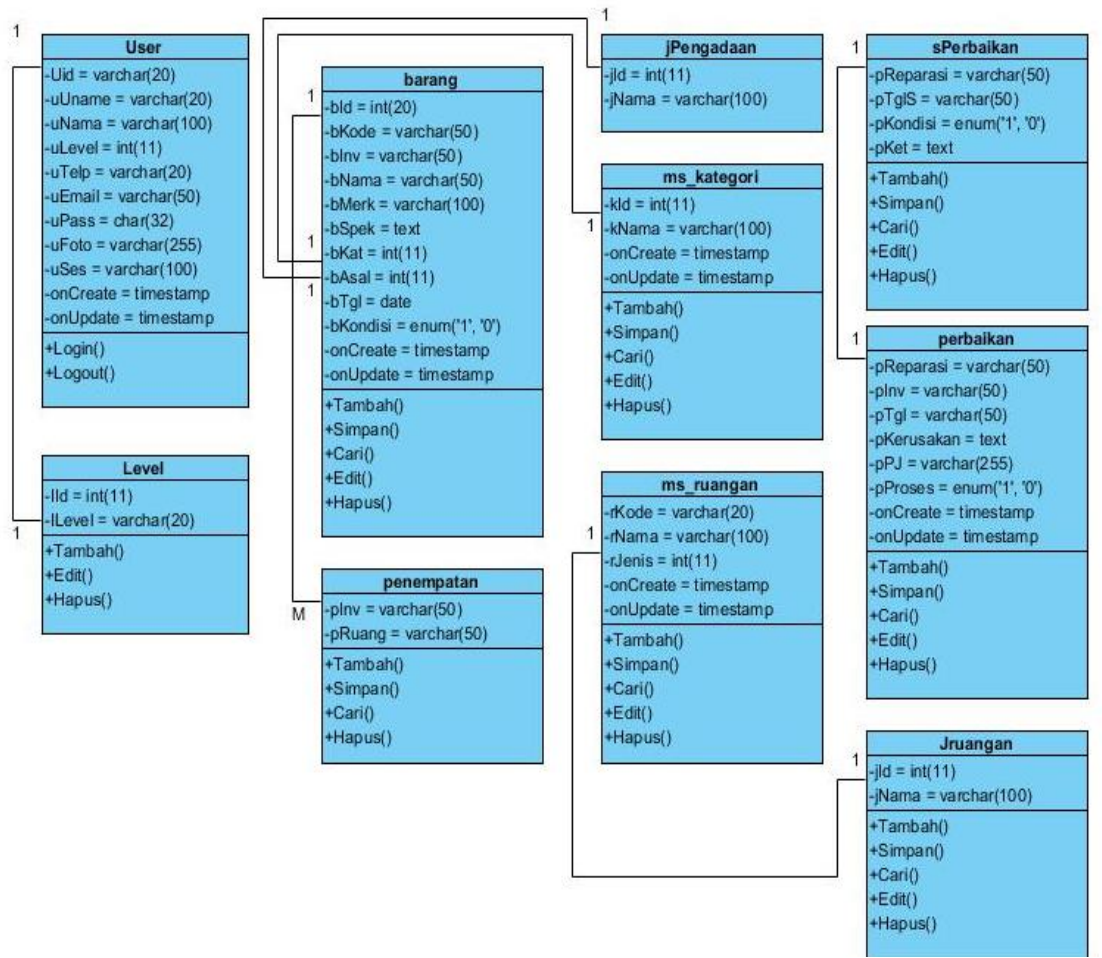

Gambar 3. Class diagram dari Sistem perawatan laboratorium komputer 


\section{Activity Diagram}

Pada saat masuk dan mengelola data pada sistem informasi, laboran harus melakukan login terlebih dahulu dengan memasukkan username dan password. Hak yang dapat dilakukan oleh laboran adalah dapat melihat data, menginput data dan pengecekan data pada sistem perawatan laboratorium ini. Activity diagram laboran dapat dilihat pada gambar 4.

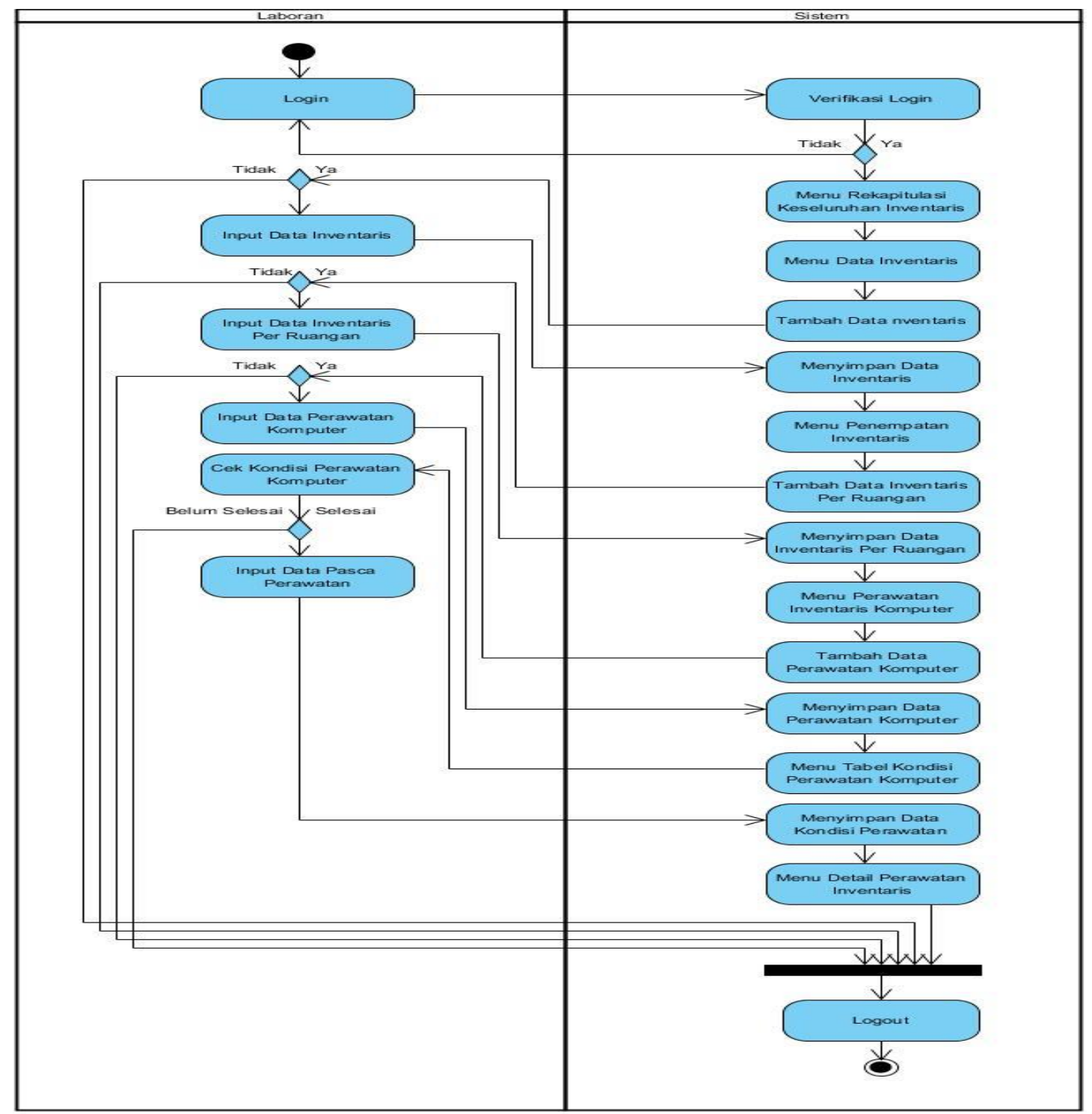

Gambar 4. Activity Diagram dari Sistem perawatan laboratorium komputer

Rancangan perawatan dan inventaris laboratorium komputer berbasis web ini dibuat dengan pemrograman berbasis web php 5 dan database MySQL. Tampilan halaman utama aplikasi perawatan dan inventaris laboratorium ini terdapat informasi tentang SMK Bhakti Anindya. Selain itu terdapaat menu inventaris yang bisa menampilkan data inventaris dan menu login untuk masuk kedalam aplikasi tersebut. Tampilan halaman utama dapat dilihat pada gambar 5. 




Gambar 5. Tampilan halaman utama aplikasi perawatan dan inventaris laboratorium

Tampilan halaman login sebagai pintu masuk laboran atau user lain ke dalam aplikasi perawatan dan inventaris laboratorium. Tampilan halaman login bisa di lihat pada gambar 6 .

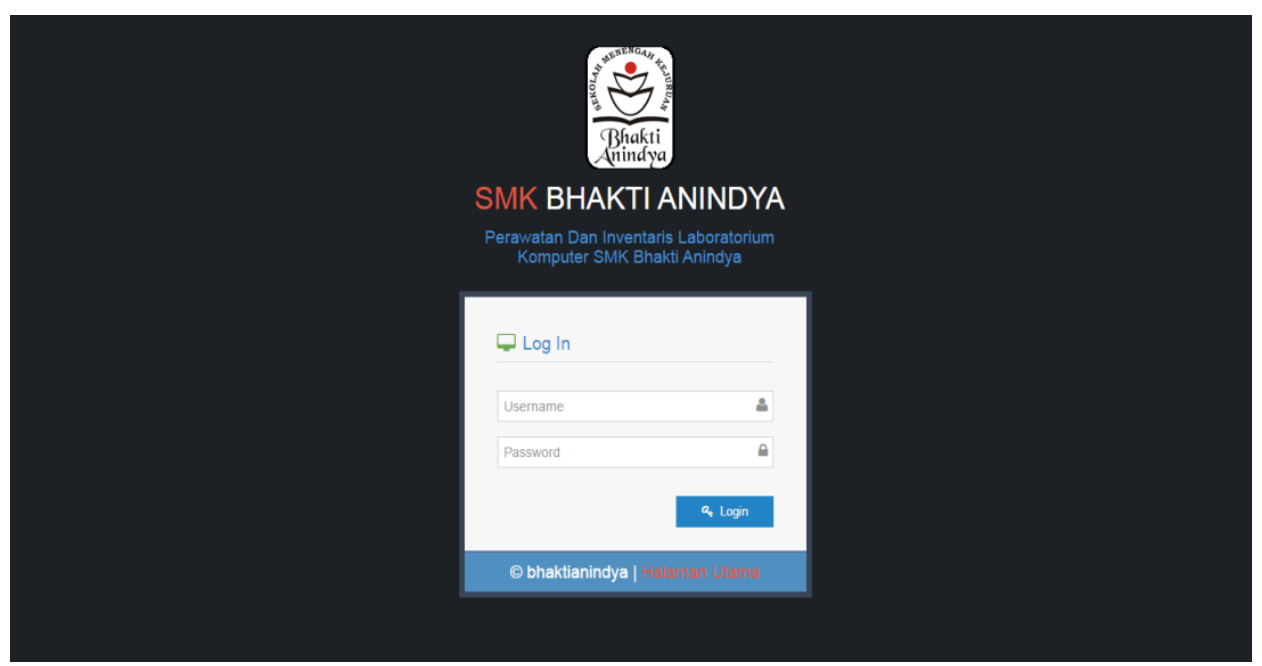

Gambar 6. Tampilan halaman login aplikasi perawatan dan inventaris laboratorium

Tampilan halaman data inventaris dalam aplikasi perawatan dan inventaris laboratorium, menampilkan data dari id barang, nama barang, merk, kategori, jenis barang, jumlah dan action. Tampilan halaman data inventaris dapat di lihat pada gambar 7.

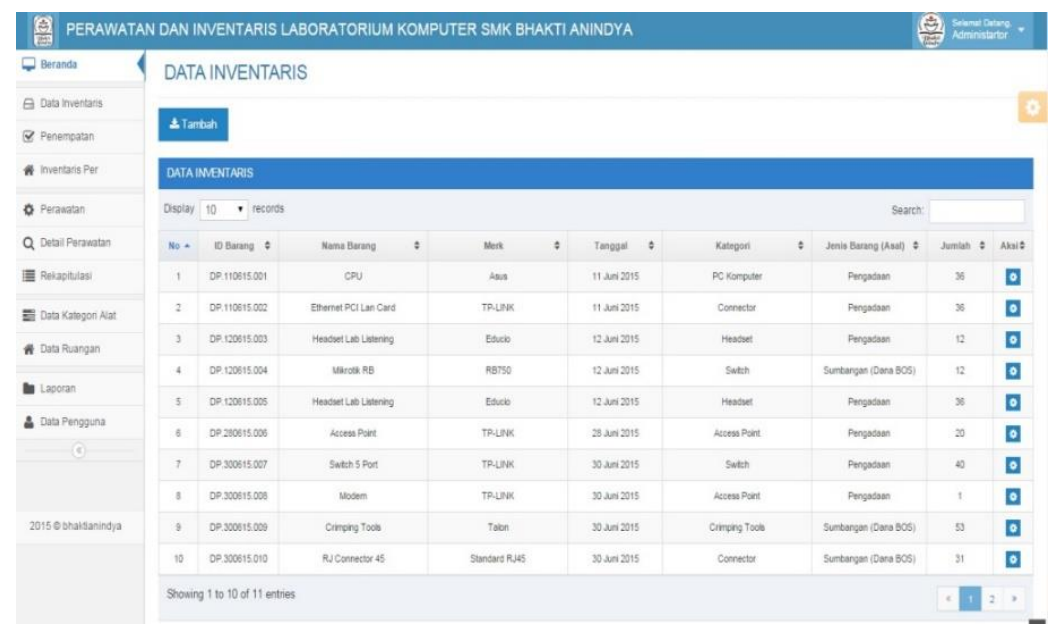

Gambar 7. Tampilan halaman aplikasi perawatan dan inventaris laboratorium 
Tampilan halaman laboran menampilkan rekapitulasi kondisi keseluruhan data inventaris. Tampilan halam laboran dapat di lihat pada gambar 8.



Gambar 8. Tampilan halaman laboran

Tampilan halaman history perawatan inventaris menampilkan informasi data barang yang sedang atau telah dilakukan perawata, beserta informasi status perbaikan. Tampilan halam history perawatan dapat di lihat pada gambar 9.

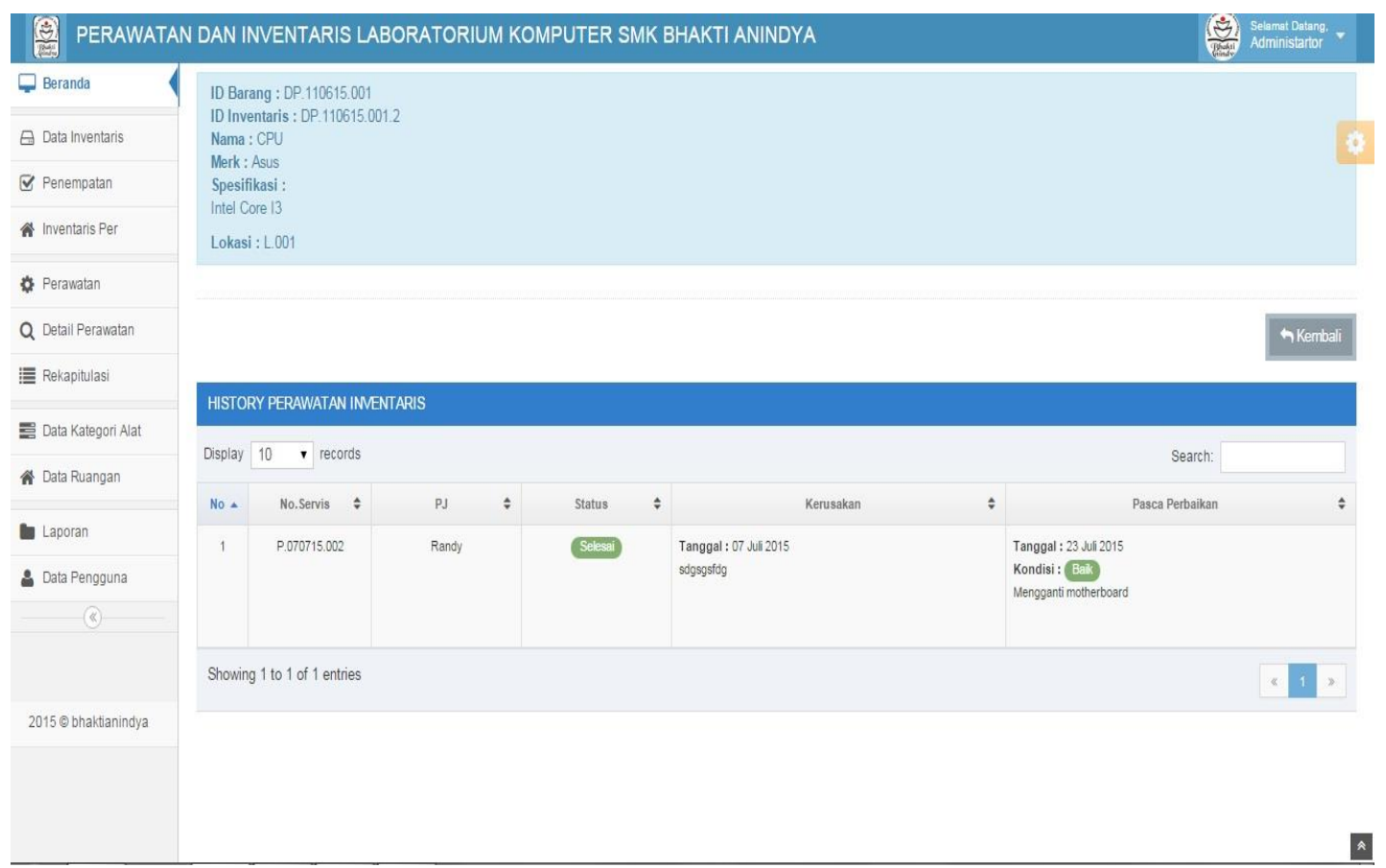

Gambar 9. Tampilan halaman riwayat perawatan inventaris 
Tampilan halaman laporan menampilkan informasi data kondisi inventaris saat ini, per bulan atau tahun, laporan inventaris per ruang dan laporan perbaikan. Tampilan halam laporan dapat di lihat pada gambar 10.

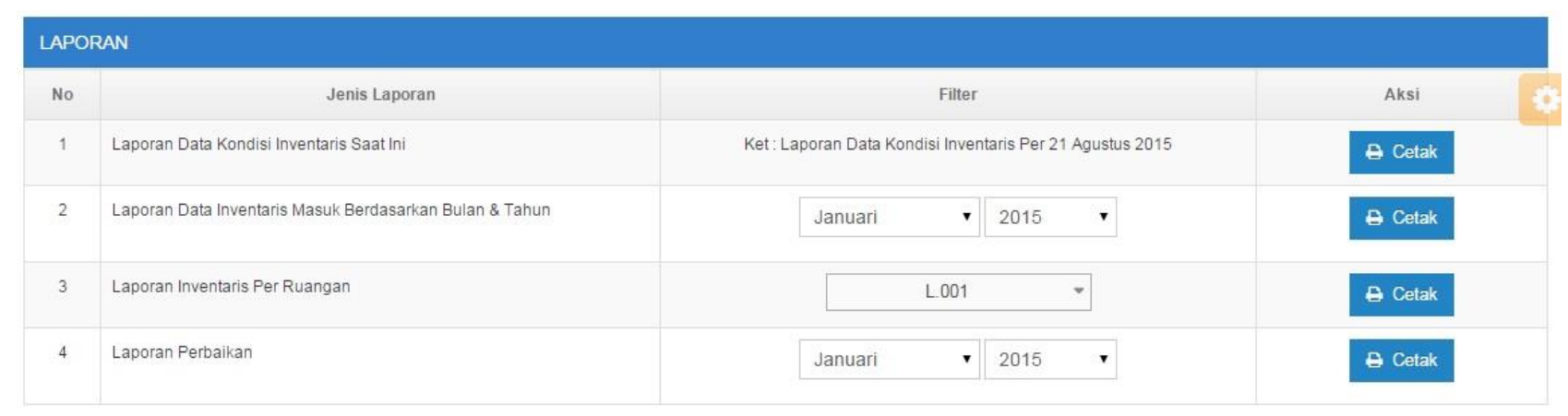

Gambar 10. Tampilan halaman laporan

Tahapan analisis sistem, perencanaan sistem, dan pembuatan aplikasi telah dilakukan, maka selanjutnya dilakukan proses testing sistemnya dan dilakukan evaluasi, sehingga aplikasi yang sudah jadi bisa dilakukan pemeliharaan dalam memperbaiki kesalahan yang ditemukan pada tahap sebelumnya.

\section{KESIMPULAN}

Dari Pembahasan diatas maka dapat disimpulkan bahwa dengan adanya sistem aplikasi perawatan dan inventaris laboratorium SMK Bhakti Anindya, dapat membantu dalam pengelolaan data inventaris dan perawatan barang. Pencatatan inventaris yang sebelumnya masih menggunakan manual dan belum menggunakan aplikasi khusus, bahkan masih menggunakan lisan yang mengakibatkan sering terjadi kesalahpahaman dalam inventaris data sudah tidak terjadi lagi.

\section{DAFTAR RUJUKAN}

[1] Prahasta, Eddy. Sistem Informasi Geografis: Konsep-Konsep Dasar (Perspektif Geodesi \& Geomatika). Informatika. Bandung. 2014.

[2] Oetomo, Budi Sutedjo. Perencanaan \& Pembangunan Sistem Informasi. Andi. Yogyakarta. 2002.

[3] Rahmiyati, Sri. Keefektifan Pemanfaatan Laboratorium di Madrasah Aliyah Yogyakarta. Jurnal. Penelitian dan Evaluasi Pendidikan. 2008.

[4] Wahid Luthfi, Hisyam. Sistem Informasi Perawatan Dan Inventaris Laboratorium Pada SMK Negeri 1 Rembang Berbasis Web. Journal Speed - Sentra Penelitian Engineering dan Edukasi. 2011.

[5] Nuraeni, F., Muzifar, T., Suparman, NGH., Sistem Informasi Inventori Barang Laboratorium Komputer Berbasis Android di STMIK Tasikmalaya. Seminar Nasional Informatika 2014.

[6] Syafrizal, R., Tabrani, A. (2021). Designing a Pustekipad Computer Laboratory Loan Application for Learning ICT Subjects. MOTIVECTION : Journal of Mechanical, Electrical and Industrial Engineering, 3(2), 51-58. https://doi.org/10.46574/motivection.v3i2.85 